\title{
ПОНЯТТЯ ПОВЕРНЕННЯ ОБВИНУВАЛЬНОГО АКТУ ТА КЛОПОТАННЯ ПРО ЗАСТОСУВАННЯ ПРИМУСОВИХ ЗАХОДІВ МЕДИЧНОГО АБО ВИХОВНОГО ХАРАКТЕРУ ПРОКУРОРУ
}

\begin{abstract}
Анотація. Стаття присвячена дослідженню проблематики категоріального визначення поняття повернення обвинувального акту та клопотання про застосування примусових заходів медичного або виховного характеру прокурору. На основі аналізу основних ознак поняття повернення обвинувального акту та клопотання про застосування примусових заходів медичного або виховного характеру прокурору, що характеризують його зміст та сутність сформульовано визначення цього поняття. Таким чином, повернення обвинувального акту та клопотання про застосування примусових заходів медичного або виховного характеру прокурору - це інститут кримінального процесуального права, що представляє собою сукупність кримінальних процесуальних норм, що регламентують прийняття судом за клопотанням сторони або за власною ініціативою рішення про усунення обставин, що перешкоджають розгляду кримінального провадження судом (якщо це не пов'язано з заповненням неповноти досудового розслідування), які суд не може усунути самостійно, а також норм, що встановлюють підстави і порядок направлення судом акту та клопотання прокурору, а також регулюють процесуальні відносини між учасниками кримінального провадження, 3 приводу усунення виявлених судом перешкод для вирішення кримінального провадження по суті.
\end{abstract}

Повернення обвинувального акту та клопотання про застосування примусових заходів медичного або виховного характеру прокурору має процесуальне та непроцесуальне значення, суттєво впливаючи на подальше просування кримінального провадження. Зокрема, обвинувальний акт як остаточне процесуальне рішення, відіграє вирішальну роль у здійсненні кримінального переслідування на стадії досудового розслідування.

Дотримання процесуальних вимог КПК України при його оформленні, структура та зміст обвинувального акту, способи викладу доказів у ньому свідчать про затвердженням обвинувальної думки прокурором. Для правильного розуміння суті обвинувального акту необхідно враховувати, що вона являє собою завершальний документ досудового розслідування, спрямована на розкриття злочину, формулювання та обгрунтування висновку щодо кримінально-релевантної події.

Ключові слова: обвинувальний акт, клопотання про застосування примусових заходів медичного або виховного характеру, повернення акту та клопотання.

Постановка проблеми. Актуальність звернення до аналізу передбаченого КПК України поняття повернення обвинувального акту та клопотання про застосування примусових заходів медичного або виховного характеру прокурору обумовлюється декількома чинниками, серед яких, безумовно, його актуаль- ність для національного законодавства, а також наявність багатьох питань, які виникають під час застосування даного порядку і потребують фахових відповідей.

В Україні відсутні фундаментальні дослідження цієї проблематики, проте іїі окремі аспекти знайшли своє відображення у наукових роботах Н.О. Зражевської [1], О.Б. Комарницької [2; 3], 0.0. Торбаса $[4 ; 5 ; 6 ; 7]$, О.Ф. Шминдрук [8; 9] та інших вчених. У зв'язку з цим дослідження передбаченого КПК України поняття повернення обвинувального акту та клопотання про застосування примусових заходів медичного або виховного характеру прокурору має здійснюватися 3 урахуванням тих наукових напрацювань, які наявні в українській кримінальній процесуальній доктрині.

Мета статті. Дослідження теоретичних засад поняття «повернення обвинувального акту та клопотання про застосування примусових заходів медичного або виховного характеру прокурору» та відповідної ії правової регламентації.

Виклад основного матеріалу дослідження. КПК України 2012 року [10] ліквідував інститут додаткового розслідування, що існував відповідно до КПК України 1960 року [11], усунувши певні види порушень, які перешкоджали забезпеченню реальної змагальності сторін, передбачивши новий інститут, як повернення обвинувального акту та клопотання про застосування примусових заходів медичного або виховного характеру прокурору (п. 3 ч. 3 ст. 314 КПК України), спрямований на усунення виявлених судом істотних порушень КПК України, без права збирання нових доказів, що обумовлює оригінальну побудову норм щодо повернення обвинувального акту та клопотання про застосування примусових заходів медичного або виховного характеру прокурору.

Процесуальний інститут повернення обвинувального акту та клопотання про застосування примусових заходів медичного або виховного характеру прокурору в сучасному вітчизняному кримінальному провадженні, замінивши інститут додаткового розслідування, став важливою новацією Кримінального процесуального кодексу України 2012 року стосовно кримінального провадження, який став одним 3 підсумків реалізації в КПК України положень концепції судової реформи в Україні.

Перш за все, це стосується побудови змагальної моделі кримінального провадження та означає відхід від сформованого за багато років стереотипу про те, що суд є інстанцією боротьби зі злочинністю. Такі зміни продиктовані необхідністю істотного підвищення якості досудового розслідування, процесу внесення даних до Єдиного реєстру досудових розслідувань і підтримання державного обвинувачення зі сторони обвинувачення в кримінальному провадженні. 
За думкою С.В. Дяденькіна, актуальність проблематики реалізації повернення обвинувального акту та клопотання про застосування примусових заходів медичного або виховного характеру прокурору обумовлена тими протиріччями, що виникли у зв'язку з появою нових законодавчих норм та вдосконаленням раніше діючих $[12$, с. 3]. Таким чином, оптимістичні прогнози авторів нового КПК України, як показує аналіз судової практики, більшою мірою зазнають критики, і сучасний стан досудового розслідування, як і раніше, викликає правомірні нарікання. Саме тому, одночасно $з$ прагненням підвищення його якості, слід удосконалювати і механізм усунення в судовому провадженні процесуальних помилок, який на сьогоднішній день недостатньо ефективний, i не дозволяє в повній мірі забезпечити судове провадження.

Впровадження повернення обвинувального акту та клопотання про застосування примусових заходів медичного або виховного характеру прокурору на стадії підготовчого провадження у суді першої інстанції $€$ сміливим кроком у кримінальному провадженні. Слід зауважити, що новий КПК України покликаний вирішити наболілі проблеми, проте він також породив різночитання з питань правової сутності повернення обвинувального акту та клопотання про застосування примусових заходів медичного або виховного характеру прокурору, про підстави таких повернень $\mathrm{i}$ його елементів.

Дискусійними також $є$ питання про перелік допустимих процесуальних дій та рішень у кримінальному провадженні, відповідно поверненого прокурору, про розмір оптимального терміну усунення порушень в порядку ст. 314 КПК України, i повноваження прокурора по поверненому судом обвинувального акту та клопотання про застосування примусових заходів медичного або виховного характеру. Також залишаються не визначеними і види порушень, які можуть бути підставами повернення обвинувального акту та клопотання про застосування примусових заходів медичного або виховного характеру прокурору.

В будь-якому випадку, прокурор зобов'язаний скласти обвинувальний акт без допущення порушення прав та свобод людини. Для виконання завдання кримінального провадження (ст. 2 КПК України) необхідно винесення законного, обгрунтованого і справедливого судового рішення, і відповідно, усунення перешкоджаючих цьому порушень, допущених на досудовому розслідуванні.

Повернення обвинувального акту та клопотання про застосування примусових заходів медичного або виховного характеру прокурору здійснюється згідно загальних правил, передбачених КПК України стосовно судового провадження у суді першої інстанції, встановленими гл. 27 КПК України. Аналіз цих положень КПК України, а також правозастосовної практики дозволяє дійти висновку про наявність особливостей, які притаманні порядку повернення обвинувального акту та клопотання про застосування примусових заходів медичного або виховного характеру. Враховуючи обмежений обсяг статті, автор звертається до дослідження лише тих питань, які пов'язані із категоріальним визначенням «повернення обвинувального акту та клопотання про застосування примусових заходів медичного або виховного характеру».

Обвинувальний акт - це процесуальний документ на досудовому розслідуванні, який підводить його підсумки та фіксує його результати. Таким чином це $\epsilon$ процесуальним рішенням, яким прокурор висуває обвинувачення у вчиненні кримінального правопорушення і яким завершується досудове розслідування (ст. 110 КПК України). Так, обвинувальний акт як процесуальний документ, має чітко та повно містити відомості передбачені ч. 2 ст. 291 КПК України. Такими відомостями є:

1. Найменування кримінального провадження та його реєстраційний номер;

2. Анкетні відомості кожного обвинуваченого (прізвище, ім'я, по батькові, дата та місце народження, місце проживання, громадянство);

3. Анкетні відомості кожного потерпілого (прізвище, ім'я, по батькові, дата та місце народження, місце проживання, громадянство);

4. Прізвище, ім'я, по батькові та займана посада слідчого, прокурора;

5. Виклад фактичних обставин кримінального правопорушення, які прокурор вважає встановленими, правову кваліфікацію кримінального правопорушення 3 посиланням на положення закону і статті (частини статті) закону України про кримінальну відповідальність та формулювання обвинувачення;

6. Обставини, які обтяжують чи пом'якшують покарання;

7. Розмір шкоди, завданої кримінальним правопорушенням;

8. Розмір витрат на залучення експерта;

9. Дату та місце його складання та затвердження.

Як і будь-який документ, обвинувальний акт може містити недоліки. Недоліки можуть мати процесуальний або фактичний (непроцесуальний) характер. Існує декілька підходів до того, яким чином використовувати такі недоліки:

1) з метою спростування обвинувачення після призначення до розгляду кримінального провадження;

2) подавати клопотання про повернення обвинувального акту та приведення у відповідність до вимог КПК України, вказавши на окремі недоліки;

3) подавати клопотання про повернення обвинувального акту та приведення у відповідність до вимог КПК України, вказавши на всі недоліки.

При обранні конкретного підходу потрібно враховувати ряд факторів та наслідків.

Ключовими елементами інституції 3 повернення обвинувального акту та клопотання про застосування примусових заходів медичного або виховного характеру прокурору є:

1) підстави повернення обвинувального акту та клопотання про застосування примусових заходів медичного або виховного характеру прокурору;

2) сутність інституту, яка полягає у відновленні порушених прав учасників кримінального провадження, в тому числі права на судовий захист і доступ до правосуддя шляхом усунення перешкод для розгляду кримінального провадження по суті;

3) процесуальний порядок повернення обвинувального акту та клопотання про застосування примусових заходів медичного або виховного характеру прокурору;

4) вчинення процесуальних дій і прийняття процесуальних рішень, які відновлюють порушені права учасників кримінального провадження і усувають перешкоди до розгляду кримінального провадження по суті;

5) процесуальні відносини, що виникають у зв'язку 3 поверненням обвинувального акту та клопотання про засто- 
сування примусових заходів медичного або виховного характеру прокурору і відновленням порушених прав учасників кримінального провадження, шляхом ліквідації перешкод для судового розгляду по суті.

За думкою О.Ф. Шминдрук, процедура повернення обвинувального акту, клопотання про застосування примусових заходів медичного або виховного характеру прокурору, як і направлення кримінального провадження до відповідного суду для визначення підсудності, у підготовчому судовому засіданні має змагальний характер. Як правило, ці питання вирішуються за клопотанням сторін, проте зважаючи на те, що відповідність обвинувального акту, клопотання про застосування примусових заходів медичного або виховного характеру, клопотання про звільнення від кримінальної відповідальності вимогам КПК є передумовою для подальшого судового розгляду, а тому суд вправі з власної ініціативи поставити це питання на обговорення учасників провадження [9, с. 122].

Положення про повернення обвинувального акту та клопотання про застосування примусових заходів медичного або виховного характеру прокурору в системі діючих норм КПК України та загальновизнаних принципів і норм міжнародного права слід розглядати як один з важливих елементів механізму забезпечення права обвинувачених на справедливий судовий розгляд.

Основними аспектами, визначаючими його значення $€$ забезпечення шляхом поняття повернення обвинувального акту та клопотання про застосування примусових заходів медичного або виховного характеру прокурору конституційних прав обвинуваченого та потерпілого на судовий захист і доступ до правосуддя, а також реалізація вимоги про розгляд кримінального провадження в розумні строки.

Одним із принципових положень, що визначають сутність повернення обвинувального акту та клопотання про застосування примусових заходів медичного або виховного характеру прокурору є питання про стадії судового провадження, коли суд може прийняти рішення про поняття повернення обвинувального акту та клопотання про застосування примусових заходів медичного або виховного характеру прокурору.

Логічним $є$ висновок про те, що повноваженнями на винесення подібних рішень має тільки суд першої інстанції на підготовчому судовому провадженні. Поняття і сутність повернення обвинувального акту та клопотання про застосування примусових заходів медичного або виховного характеру прокурору знаходить своє вираження і в характері процесуальних відносин, що виникають між учасниками кримінального провадження 3 приводу усунення виявлених судом перешкод.

На основі аналізу основних ознак поняття повернення обвинувального акту та клопотання про застосування примусових заходів медичного або виховного характеру прокурору, що характеризують його зміст та сутність сформульовано визначення цього поняття. Таким чином, повернення обвинувального акту та клопотання про застосування примусових заходів медичного або виховного характеру прокурору - це інститут кримінального процесуального права, що представляє собою сукупність кримінальних процесуальних норм, що регламентують прийняття судом за клопотанням сторони або за власною ініціативою рішення про усунення обставин, що перешкоджають розгляду кримінального провадження судом (якщо це не пов'язано з заповненням неповноти досудового розслідування), які суд не може усунути самостійно, а також норм, що встановлюють підстави і порядок направлення судом акту та клопотання прокурору, а також регулюють процесуальні відносини між учасниками кримінального провадження, 3 приводу усунення виявлених судом перешкод для вирішення кримінального провадження по суті.

Повернення обвинувального акту та клопотання про застосування примусових заходів медичного або виховного характеру прокурору має процесуальне та непроцесуальне значення, суттєво впливаючи на подальше просування кримінального провадження. Зокрема, обвинувальний акт як остаточне процесуальне рішення, відіграє вирішальну роль у здійсненні кримінального переслідування на стадії досудового розслідування. Дотримання процесуальних вимог КПК України при його оформленні, структура та зміст обвинувального акта, способи викладу доказів у ньому свідчать про затвердженням обвинувальної думки прокурором.

Для правильного розуміння суті обвинувального акту необхідно враховувати, що вона являє собою завершальний документ досудового розслідування, спрямована на розкриття злочину, формулювання та обгрунтування висновку щодо кримінально-релевантної події, викриття обвинувачених. Така роль обвинувального акту визначається тим, що в ньому, на підставі результатів проведеного досудового розслідування викладається остаточне формулювання обвинувачень у матеріально-правовому сенсі, що виражає його впевненість у винуватості конкретної особи, що, за затвердженням цього акту прокурором, означає завершення кримінального провадження на досудовому розслідуванні. Після цього кримінальне провадження буде продовжено в судовому порядку.

Таким чином, поняття та значення повернення обвинувального акту та клопотання про застосування примусових заходів медичного або виховного характеру прокурору витікає 3 виявлення і розуміння чинників, які сприяють формуванню процесуальних підстав для повернення обвинувального акту прокурору.

Висновки. Розглянути питання, не вичерпуючи проблематику категоріального визначення поняття повернення обвинувального акту та клопотання про застосування примусових заходів медичного або виховного характеру прокурору, наочно підтверджують актуальність його дослідження 3 метою формування науково обгрунтованих пропозицій, спрямованих на удосконалення кримінального процесуального законодавства України в цій частині.

1. Зражевська Н.О. Попередній розгляд справи суддею у кримінальному судочинстві України: автореф. дис. ... канд. юрид. наук / Н.О. Зражевська. Київ : б. в., 2011. 16 с.

2. Комарницька О., Радіонов В. Актуальні питання повернення обвинувальних актів та прийнятих за цим рішень / О. Комарницька, В. Радіонов // Вісник прокуратури. 2015. № 6. С. 73-85.

3. Комарницька О. Підстави повернення обвинувального акту прокурору. Електронний ресурс. URL: http://www.lex-line.com.ua/ ?language $=$ ru\&go=full_article\&id $=1953$.

4. Торбас О.О. Порівняльна характеристика обвинувального акту та обвинувального висновку за старим та чинним процесуальним законодавством / О.О. Торбас // Правова система Украӥни: сучасні тендениіїта фактори розвитку: матер. Міжнар. наук.-практ. конф. (м. Запоріжжя, 25-26 січня 2013 р.). У 2-х ч. Запоріжжя : Запорізька міська громадська організація «Істина», 2013. Ч. II. С. 96-98. 
5. Торбас О.О. Момент закінчення досудового розслідування за КПК 2012 р. / О.О. Торбас // Актуальні питання теорії та практики застосування сучасного вітчизняного та міжнародного права : матер. Міжнар. наук.-практ. конф. (м. Київ, 15-16 червня 2013 р.). К. : Центр правових наукових досліджень, 2013. С. 103-106.

6. Торбас О.О. Закриття кримінального провадження за новим Кримінальним процесуальним кодексом України: характеристика деяких новел / O.O. Торбас // Теоретичні та практичні проблеми забезпечення сталого розвитку державності та права : матер. Міжнар. наук. конф. (м. Одеса, 30 листопада 2012 р.) Т. 2 / відп. за вип. д. ю. н., проф. В.М. Дрьомін; Націон. ун-т «Одеська юридична академія». Одеса : Фенікс, 2012. С. 341-343.

7. Торбас О.О. Повноваження прокурора на стадії досудового розслідування при затверджені обвинувального акта / О.О. Торбас // Науковий вісник Херсонського державного університету. Серія «Юридичні науки». 2013. № 4. С. 171-174.

8. Шминдрук О.Ф. Щодо окремих проблем здійснення підготовчого провадження в суді першої інстанції / О.Ф. Шминдрук // Матеріали V Міжнародної науково-практичної конференції «Малиновські читання», м. Острог, 30 вересня-1 жовтня 2016 р. Острог : Видавництво Національного університету «Острозька академія». 2016. С. 233-234.

9. Шминдрук О.Ф. Підготовче провадження в кримінальному процесі України: дис. на здобуття наукового ступеня кандидата юридичних наук: спец. 12.00.09 «Кримінальний процес та криміналістика; судова експертиза; оперативно-розшукова діяльність» / Шминдрук Ольга Федорівна; Академія адвокатури України. Київ, 2016. 210 с

10. Кримінальний процесуальний кодекс України [Електронний ресурс]: Закон від 13 квітня 2012 року № 4651-VI / Верховна Рада України // Відомості Верховної Ради України. К., 2012. URL: http://zakon4.rada.gov.ua/laws/show/4651-17.

\begin{tabular}{l} 
11. Кримінально-процесуальний кодекс України [Електро- \\
\hline
\end{tabular} нний ресурс]: Закон від 28 грудня 1960 року № 2 / Верховна Рада України // Відомості Верховної Ради України. К., 1960. URL: http://zakon5.rada.gov.ua/laws/show/1001-05/print14598385 76065491.

12. Дяденькин С.В. Возвращение уголовного дела прокурору для устранения препятствий его рассмотрения судом : автореферат диссертации на соискание ученой степени кандидата юридических наук. Специальность 12.00.09 - уголовный процесс, криминалистика; оперативно-розыскная деятельность / С.В. Дяденькин; Науч. рук. А.В. Кудрявцева. Челябинск, 2010. 30 с.
Kedik V. The notion of the return of the indictment and the petition for the use of compulsory measures of medical or educational nature of the prosecutor

Summary. The article is devoted to the study of the problem of categorical definition of the return of the indictment and the request for the use of compulsory measures of medical or educational nature of the prosecutor. On the basis of the analysis of the main features of the notion of return of the indictment and the request for the use of compulsory measures of a medical or educational nature of the prosecutor, characterizing its content and essence, formulated the definition of this concept.

Thus, the return of the indictment and the petition for the use of compulsory measures of medical or educational nature of the prosecutor - is the institution of criminal procedural law, which is a set of criminal procedural rules governing the adoption by the court at the petition of the party or on its own initiative, the decision to eliminate the circumstances that prevent trial of a criminal proceeding (if it is not connected with filling the incompleteness of a pre-trial investigation), which the court can not eliminate on its own and.

The rules establishing the grounds and procedure for the submission by the court of the act and the petition of the prosecutor, as well as regulate the procedural relations between the participants in the criminal proceedings, on the elimination of obstacles detected by the court to resolve the criminal proceedings in substance. The return of the indictment and the petition for the use of compulsory measures of medical or educational nature of the prosecutor has a procedural and non-procedural significance, substantially affecting the further promotion of criminal proceedings.

In particular, the indictment as a final procedural decision plays a decisive role in the criminal prosecution at the stage of pre-trial investigation. Compliance with the procedural requirements of the CPC of Ukraine when it is formalized, the structure and content of the indictment, and the way in which evidence is evidenced by the prosecutor's confirmation of the indictment. In order to understand the essence of the indictment, it is necessary to take into account that it constitutes the final document of a pre-trial investigation aimed at disclosing a crime, the formulation and substantiation of a conclusion on a criminal-relevant event.

Key words: accusatory act, application for the use of compulsory measures of medical or educational nature, return of the act and petition. 